\title{
The Ovarian Hypofunction: A Case in Cow Management Therapy
}

\author{
Herry Agoes Hermadi, Mas'ud Hariadi and and Suherni Susilowati \\ Infertility Laboratory, Department of Reproduction \\ Veterinary Faculty, Airlangga University
}

\begin{abstract}
There were two FH (Friesian Holstain) cows in Lani Dairy Farm Surabaya that suffered from ovarian hypofunction after therapy as follows: In the case of ovarian hypofunction, management problems were solved by improving feeding systems for increasing body condition score, which was expected to increase more than twofold by providing green feed $10 \%$ of body weight per day. Natural recovery will occur if the cow is given with $17 \%$ protein concentrate provided $2 \%$ of the BW per day for one month. Impaired function of the anterior pituitary gland can cause, among others, ovarian hypofunction with smooth surface of the ovaries because there was no follicle and corpus luteum growth, although the size is normal. This is because the decrease in FSH and LH in the blood was very low, the food was less, poor sanitation and the animals were too long in the cow shed. Diagnosis can be made by rectal palpation and ultrasonography. To stimulate estrus and ovulation, we used a combination of gonadotropin preparations with CIDR (Control Internal Drug Release),PMSG (Pregnant Mare Serum Gonadotropin) Folligon intervet 500 IU by intramuscular, PGF2 alpha (Lutalyse). After the BCS more than 2. In conclusion ovarian hypofunction can be treated if body score condition less than 2 and improve feeding management as soon as possible to obtain BCS of more than 2
\end{abstract}

Keywords: ovarian hypo function, BCS, PMSG, CIDR and PGF2 alpha

\section{INTRODUCTION}

Improvement of living standards, intellect and welfare of the people is the goal of national development. Development and improvement of livestock production is one of the factors supporting the achievement of those goals. Various activities have been carried out to improve the productivity of livestock. However, rapid population growth and increased purchasing power of the people cause the demand for meat and milk becomes beyond their production. In the decade of the $80 \mathrm{~s}$, cattle population decreased $1.46 \%$ per year. It was because the slaughter rate, especially the slaughter of productive female cattle and livestock deaths due to disease was higher than the birth rate. Low birth rates and a decline in livestock population is the mainly influenced by the low level of livestock fertility and perinatal death. Birth rates and population growth is the problem of livestock reproduction or livestock breeding (Adjid. 2004). In the dairy industry worldwide, reproductive disorders are a major cause of economic losses and a challenge to scientists and technicians. In recent decades, declining fertility and increasing milk production have been widely reported in dairy cattle. In this article, the relationships between milk productions, ovarian disorders and fertility in high producing dairy herds are briefly described. We carried out a retrospective study of 23204 
lactations included in a reproductive control program, a geographical area experiencing both warm and cool conditions. (Yániz, et al, 2008).

Actually, if we look at the cases of reproductive disorders and report the results of insemination in East Java, there are cases that are important to know but has never been reported, that is the incidence of repeated mating or "repeat breeding". Until now there are no exact data on the percentage of "repeat breeders" cows, although there are a lot of complaints about the failure of artificial insemination breeder or a new pregnancy occurs after a few times of artificial insemination. One of the difficulties encountered in the field is that the breeder is not carrying artificial insemination card, so he does not know or forgets the time and frequency of insemination. The next difficulty is that cattle brought are not often cattle with reproductive disorder complaints, or in the other words, it was not on target, in addition to inadequate facilities. Two main objectives of the program of artificial insemination in cattle are to improve the genetic quality of the local livestock and prevent or eliminate sexually transmitted diseases. When compared to natural mating, artificial insemination is much more efficient in saving the stud, and the breadth and speed of deployment of superior cattle breeds produced. Beside these advantages, artificial insemination also contains a very high risk if the selection of bulls is less well in frozen semen production process, or the handling and distribution in the field is not done genuinely. The potential damage is doubled since sexually transmitted diseases and genetic defects descent are fast and widespread both nationally and internationally (Frost et al, 1981). Artificial insemination has been carried out in our country for about half a century. However, the results from the ability of artificial insemination in the doubling superior descent are doubtful. Our livestock population increase is still very slow and cannot meet domestic demand. This paper discusses some of the many kinds of reproductive problems found in the field and some sexually transmitted diseases that can spread through artificial insemination. Furthermore, we will outline in this paper some cases of the results of Reproductive Disorders Control team in several districts in East Java, and some kind of diseases in cattle that can be transmitted through artificial insemination.(Putro, 1991).

\section{Reproductive Disorders Cases in East Java}

Cooperation between East Java Provincial Animal Husbandry and Veterinary Medicine Faculty of Airlangga University has pioneered since the 1970s, specifically for the prevention of reproductive disorders, formed the "Sterility Eradication" team. Until now the team has been renamed several times, among others, "Sterility Control Team" and others, and now better known as the team of "Reproductive Disorders Management". In handling cases in the field of reproductive disorders, the role of Veterinary Medicine Faculty of Airlangga University' is still regarded as lacking, because it has only limited roles in making a diagnosis, whereas it does not participate in the treatment and monitoring treatment outcomes. Veterinary Medicine Faculty of Airlangga University in its role in the field from year to year, especially in the diagnosis of reproductive disorders, reached only less than $10 \%$ of the expected target. Table 1 contains the results of the examination of reproductive disorders in East Java in 2009 and 2010. 
Table 1. Reproductive Disorders Examination Results in Cows in East Java in 2009 and 2010

\begin{tabular}{|c|l|c|c|c|c|}
\hline \multirow{2}{*}{ No. Type of Cases } & \multicolumn{2}{|c|}{ Number of Cases } & \multicolumn{3}{c|}{$\%$} \\
\cline { 3 - 6 } & & 2009 & 2010 & 2009 & 2010 \\
\hline 1. & Ovarian hypofunction & 1220 & 1131 & 4.7 & 6.28 \\
2. & Ovarian atrophy & 206 & 228 & 0.8 & 1.3 \\
3. & Ovarian cysts & 197 & 350 & 0.7 & 1.94 \\
4. & Persistent CL & 926 & 1032 & 3.6 & 5.73 \\
5. & Endometritis & 432 & 492 & 1.7 & 2.73 \\
6. & Pyometra & 98 & 77 & 0.4 & 0.43 \\
7. & Uterine tumor & 12 & 3 & 0.05 & 0.03 \\
8. & Others & 116 & - & 0.45 & - \\
\hline & Total cases & 3207 & 3310 & 12.35 & 22.72 \\
\hline & Total examined cows & 26 & 17 & & \\
\hline
\end{tabular}

From the results of these reproductive disorders (Table 1), ovarian hypofunction case occupies the highest position followed by the corpus luteum and later persistent endometritis. Theoretically the cases above will be discussed in the next sub chapter. (Hariadi et al.2010)

\section{MATERIALS AND METHODS}

\section{Treatment of Ovarian Hypofunction}

Two FH (Friesian Holstain) cows were present at Lani Farmer Dairy Farm Surabaya that suffered from ovarian hypofunction after therapy as follows: In the case of ovarian hypofunction, management problems were solved by improved feeding systems for improved body condition score, which was expected to increase more than twofold by providing feed. Management system improvement should be done to identify the mistake and feeding was improved with the provision of green feed $10 \%$ of body weight per day. Natural recovery will occur if the cow is given with $17 \%$ protein concentrate provided $2 \%$ of the BW per day for 1 month. There were two FH (Friesian Holstain) cows in Lani Farmer Dairy Farm Surabaya that suffered from ovarian hypofunction after therapy as follows: In the case of ovarian hypofunction, management problems were solved by improved feeding systems for improved body condition score, which was expected to increase more than twofold by providing green feed $10 \%$ of body weight per day. Natural recovery will occur if the cow is given with $17 \%$ protein concentrate provided $2 \%$ of the BW per day for 1 month. Impaired function of the anterior pituitary gland can cause, among others, ovarian hypofunction with slippery surface because there was no follicle and corpus luteum growth, although the size was normal. It was because the decrease in FSH and LH in the blood was very low, the food was less, sanitation was poor and the animals were too long in the cage.(Hariadi et al.2011; Morrow, 1980; Eaglesome, and Garcia, 1997)

Diagnosis could be made by rectal palpation and ultrasonography.Impaired function of the anterior pituitary gland could cause, among other things, ovarian hypofunction. Ovarian surface was slippery because there was no growth of the follicle and corpus luteum at this state of the normal ovary. It was due to deep decrease in FSH and LH in the blood, bad sanitation and animals were too long in the cage with feeding of poor quality and quantity. The apparent clinical symptom was anestrus. If body condition was poor and feed shortage was taking place in a long time, ovarian hypofunction will turn into ovarian atrophy. Atrophic 
ovaries were ovaries smaller than normal and with a slippery surface because the follicles do not grow so the reproduction process was not running at all. Livestock body condition was poor with clinical symptoms of very long anestrus. Practical applications of ultrasound in bovine reproduction include imaging of the ovary as a diagnostic aid, examination and confirmation of ovarian cysts, early pregnancy detection, and identification of infertility. Although rectal palpation was the established method for conducting reproductive examinations, the information gathering capabilities of ultrasonic imaging far exceed those of rectal palpation. Assessment of pregnancy status and fetal viability early post breeding could significantly improve reproductive efficiency. Such methods can play a key role in reproductive management to rapidly return open animals to the breeding program. Early pregnancy detection was only useful when techniques have a high-level of accuracy for detection of infertility. (Alemayehu. 2013). The symptom of ovarian hypofunction was anestrus. Subordinate follicles did not develop into dominant follicle, BCS $<2$, once reproduced or having offspring. The cause of ovarian hypofunction was failed management factors, such as overpopulation, environmental factors, and the cage was too hot and crowded. The differential diagnosis of ovarian hypofunction was ovarian hypoplasia in which the animal was obese, infertile since being calf, and small vulva and genitalia due to genetic factors. If HP was not treated, the ovaries will shrink, which was designated as atrophy (Toelihere, 1981).

\section{RESULTS}

Diagnosis could be made by rectal palpation and ultrasonography. To accelerating estrus and ovulation LH and FSH preparation in combination with PMSG Folligon intrevet500 IUnit IM and CIDR progesterone preparation. Ovarian atrophy can be distinguished from ovarian hypoplasia caused by genetic factor. In the state of hypoplasia, the ovary was similar to the state of ovarian atrophy, which was very small, but the physical state of the body was much fatter. Treatment of ovarian hypo function could be done it by improving the feed quality, cages should be cleaned frequently and the cattle should be frequently grazed. When the condition has improved, the preparations PMSG could be given by intramuscular.(Darrel and Kesler 2002, Opsomer et al. 2000).We used ultrasonography with typical of sonovet with linear probe that should be inserted into rectal palpation for knowing the surface of the ovary and follicle condition. There was no growth of subordinate follicles that would become predominant follicles due to FSH and LH deficiency. The subordinate follicles structure included measurement around less than $5 \mathrm{ml}$, the color of follicles solution was black or hypoechogenic.After 30-day management therapy we injected PMSG Folligon 500 IU by intramuscular 2 days thereafter. The echo texture was a terminology used in USG to describe tissue structure relative to the surrounding tissue. After the injection of Folligon (PMSG), the figure changed. The follicles became predominant with the diameter around $14 \mathrm{~mm}$, which would be ovulated with hypoechogenic.The sign of estrus would show as soon as ovulation takes place and we straightly carried out insemination, and finally we found that the cattle was successfully pregnant. Then, 30 days later we identified the foetus with vertebrae, which was hyperechogenic, the heat in isoechogenic, and the water amnion with black color in hypoechogenic. 


\section{DISCUSSION}

\section{Ovarian Hypofunction and Atrophy}

Impaired function of the anterior pituitary gland can cause, among other things, ovarian hypofunction. Ovarian surface is smooth because there is no growth of the follicle and corpus luteum at this state of the normal ovary. This is due to FSH and LH decrease in the blood. Animals are too long in the cage with feeding of poor quality and quantity (Radostits $0 \mathrm{M}$ and Blood D C, 1985). Clinical symptom seen is anestrus. If poor body condition and feed shortage in a long time, ovarian hypofunction will turn into ovarian atrophy. Atrophic ovaries are ovaries smaller than normal and with a slippery surface because the follicles do not grow so the reproduction process is not running at all. Livestock body condition is thin with clinical symptom of very long anestrus.Diagnosis can be made by rectal palpation and ultrasonography. Management system needs to be improved to find the location of faults and to improve the quality. If the BCS had increased more than 2, rectal palpation should be done to observe the structure and development of the ovary. Then, in order to quickly put the cattle back into the cycle and to stimulate the onset of estrus and ovulation, the animal were supplied with FSH and LH preparations of progesterone (C1DR or PRID) can help (McDougall and Compton, 2005; Pemayun, 2009.).Ovarian atrophy can be distinguished from ovarian hypoplasia caused by genetic factors. Ovarian hypoplasia circumstances are similar to the circumstances of ovarian atrophy, in which the ovaries are very small but the physical state of the body is much fatter. Ovarian hypoplasia is a condition where one or both ovaries did not grow from birth to adulthood, so the ovaries cannot be found. If the ovaries are not present, they look like just a thickening of the soft head of a pin. Females who suffer from this disorder are completely sterile. (Valyushkin and Gukov.1980).

\section{CONCLUSION}

Ovarian hypofunction could be treated if body score condition was less than 2 and feeding management was improved as soon as possible to obtain BCS of more than 2 .

\section{REFERENCES}

Abdul Adjid RM. 2004. Strategi Alternatif Pengendalian penyakit Reproduksi Menular untuk Meningkatkan Efisiensi Reproduksi SapiPotong. Wartazoa 14(3):125-132.

Alemayehu L. 2013. The Role of Trans-Rectal Ultrasonography in Artificial Insemination Program .Additional information is available at the end of the chapter.http://dx.doi.org/10.5772/52721

Morrow DA, 1980. Current therapy in theriogenology; Diagnosis, treatment and prevention of reproductive disease in animal.W.B.Saunders Company Philadelphia.London-Toronto.

Darrel J and Kesler,2002. Review of estrous syncrhonization systems: CIDR inserts Proceedings, The Applied Reproductive Strategies in Beef Cattle Workshop, September 56, 2002, Manhattan, Kansas,

Eaglesome MD and MM Garcia. 1997. Disease risks to animal health from artificial insemination with bovine semen. Rev. sci. tech. Off. Int. Epiz. 16(1), 215-225. 
Frost A J, Holroyd R G, Ladds, P W, and Williamson P E, 1981. Reproductive Diseases and Their Prevention.Australian Vice Chancellors Committee.

Hariadi.M, Harjopranyoto, Wurlina, HerryAgoes and Budi U, Reproductive Disorders Examination Results in Cows in East Java in 2009 and 2010 .Veterinarian Faculty Airlangga.University

Hariadi.M, Harjopranyoto, Wurlina Herry Agoes Budi U, Indah Norma and Hermin R.2011.Buku Ajar Ilmu Kemajiran pada Ternak. Departemen reproduksi Veteriner. Fakultas Kedokteran Hewan Universitas Airlangga.

McDougall,S. and C. Compton, 2005. Reproductive Performance of Anestrous Dairy Cows Treated with Progesterone and Estradiol Benzoate.J. Dairy Sci. 88:2388

Opsomer, G., Y. T. Grohn, J. Hertl, M. Coryn, H. Deluyker, and A. de Kruif. 2000. Risk factors for post partum ovarian dysfunction in high producing cows in Belgium: A field study. Theriogenology 53:841-857.

Radostits 0 M and Blood D C, 1985. Herd Health. W.B. Saunders Company. London Roberts S J, 1971. Veterinary Obstetrics and Genital Diseases.Edwards Brother Inc. Ann Arbor. Michigan.

Pemayun, T.G.O., 2009. Induction of Oestrus with PMSG and Gn-RH in the Postpartum Anoestrus Dairy Cow.Diaksespadahttp://www.bulletinveteriner.com/induksi-estrus-denganpmsg-dan-gn-rh-pada-sapi-perah-anestrus-postpartum/tanggal 11 Januari 2012

Putro, P.P., 1991. The treatment of anoestrus and sub oestrus in dairy cattle using a progesterone controlled internal drug release (CIDR) or a synthetic GonadotrophinReleasing hormone Gn-RH. Buletin FKH- UGM. Vol.10 no2.

Toelihere M R, 1981. Ilmu Kemajiran PadaTernak Sapi. Edisi Pertama. Institut Pertanian Bogor.

Valyushkin K.D and GukovF.D.1980 . Vitamin A in hypofunction of ovary [dairy cattle, chemotherapeutants- other, Byelorussain SSR]]. [Russian []VitebskijVeterinarnyj Inst. (Byelorussian SSR) Ecole Nationale Veterinaire de Toulouse, 31 (France).

$\underline{\text { Yániz J }}^{1}$, López-Gatius F, Bech-Sàbat G, García-Ispierto I, Serrano B, and Santolaria P. 2008. Relationships between milk production, ovarian function and fertility in highproducing dairy herds in north-eastern Spain. 